Đuro Jovanić, kapetan, dipl. ekon.

VP 1403,

\section{STANDARD NIJ 0115.00 ZA TESTIRANJE OTPORNOSTI ZAŠTITNIH PRSLUKA NA UBODE NOŽEM I PREDMETIMA SA OŠTRIM VRHOM}

UDC: $614.082 .2: 646.43]: 623.444 .6$

Rezime:

Standard NIJ 0115.00 (prema Nacionalnom institutu pravde SAD), namenjen je za utvrđivanje minimuma tehničkih zahteva i metoda ispitivanja otpornosti zaštitnih prsluka, koji treba da zaštite gornji deo tela od uboda nožem i predmetima sa oštrim vrhom. Područje primene ovog standarda ograničeno je samo na pretnje ubodima, a ne na balističke pretnje, poput onih koje su obuhvaćene standardom NIJ 0101.04 za testiranje balističke otpornosti zaštitnih prsluka.

Ključne reči: energija, upadni ugao, penetracija, ispravan pogodak, nož, sečivo, šilo, deformacija, zaštitni prsluk, uzorak.

\title{
NIJ 0115.00 STANDARD FOR TESTING STAB RESISTANCE OF BODY ARMOR
}

Summary:

In this work made presentation of NIJ 0115.04. (National Institute of Justice) standard, witch purpose is to establish minimum performance requirements and methods of testing for the stab resistance of body armor intended to protect the torso against slash and stab threats. The scope of the standard is limited to stab resistance only; the standard does not address ballistic threats, as those are covered by NIJ Standard 0101.04. Ballistic Resistance of Personal Body Armor.

Key words: energy, angle of incidence, penetration, fair hit, knife, blade, spike, deformation, body armor, sample.

\section{Uvod}

Pod uticajem povećanja sofisticiranosti vatrenog oružja proizvođači zaštitnih prsluka su svoja istraživanja usmerili na segment zaštite integriteta lica izloženih balističkim pretnjama, što je, uglavnom, rezultiralo zapostavljanjem oblasti zaštite od pretnji tradicionalnim - hladnim oružjem.

S druge strane, statistička ispitivanja u poslednjoj deceniji XX veka pokazala su da na pripadnike vojske i policije, pri obavljanju redovnih poslova bezbednosti, pre- ko $65 \%$ napada biva izvršeno nožem ili predmetom sa oštrim vrhom, $12 \%$ klupskim oružjem (palice, šipke, lanci, bokseri i sl.), dok se napadi vatrenim oružjem izvrše samo u $2 \%$ slučajeva (slika 1 ).

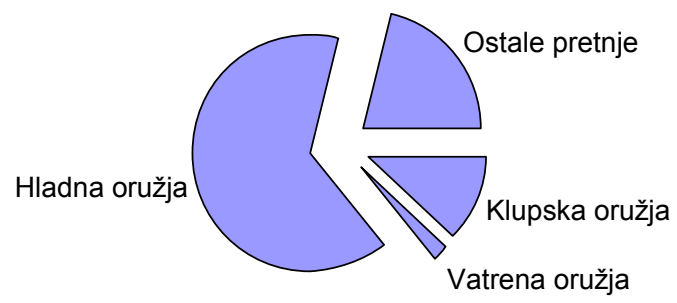

Sl. 1 - Napadi u zavisnosti od vrste oružja 


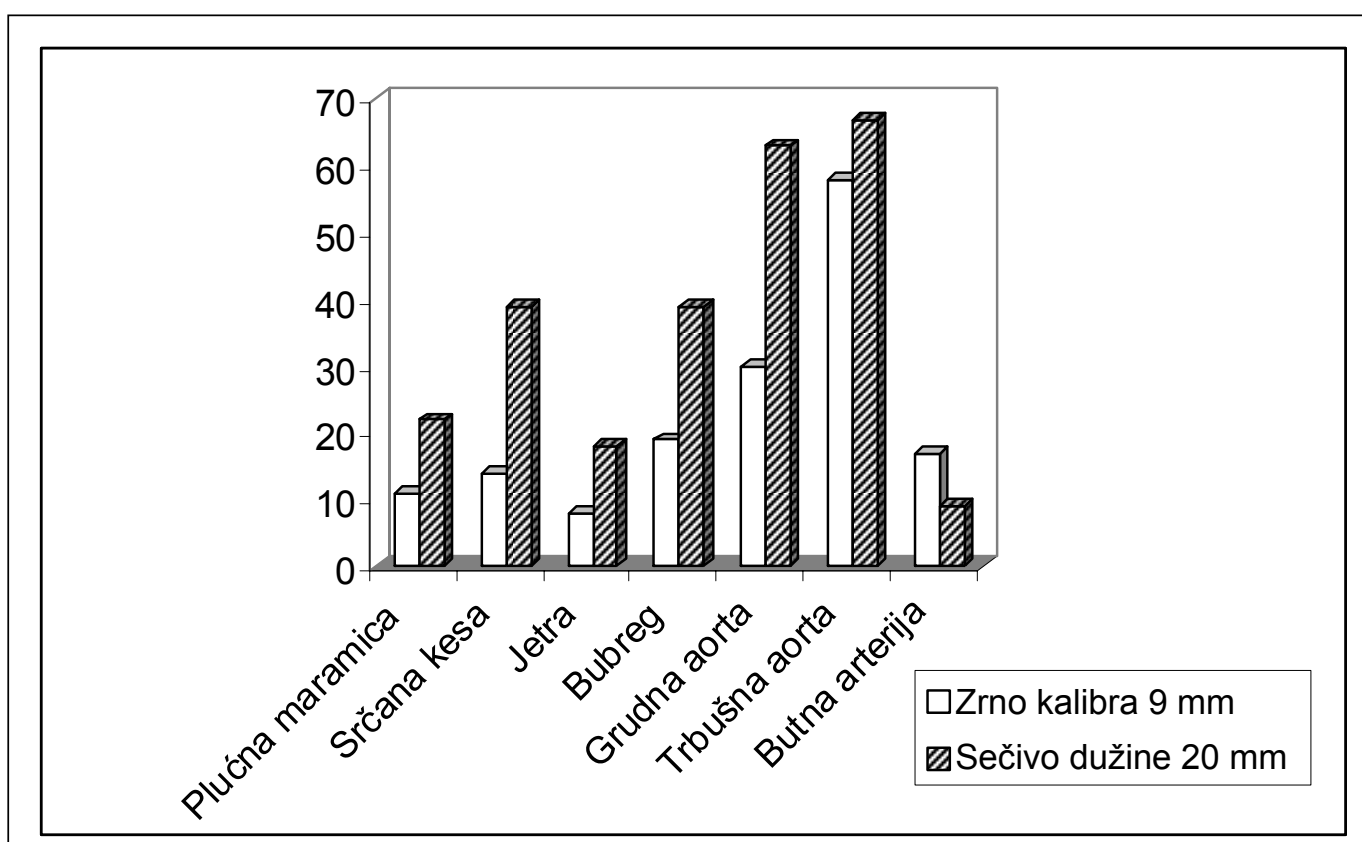

Sl. 2 - Uporedni pregled povreda nanesenih ,sečivom “ dužine $20 \mathrm{~mm}$ i zrnima kalibra $9 \mathrm{~mm}$

Statistički gledano, od 5 slučajeva povreda izazvanih nožem ili predmetom sa oštrim vrhom, čak tri imaju smrtonosan ishod. Šta više, penetracija sečivom dubine od $20 \mathrm{~mm}$ u predelu vitalnih organa, u većini slučajeva rezultuje fatalnijim ishodom nego iste povrede nanesene pojedinim zrnima kalibra $9 \mathrm{~mm}$ (slika 2).

Analizirajući navedene, kao i mnoge druge rezultate ispitivanja vezane za napade hladnim oružjem, otpočelo se sa formulisanjem standarda pomoću kojeg bi se utvrdili minimumi tehničkih zahteva $\mathrm{i}$ propisale metode ispitivanja otpornosti zaštitnih prsluka, koji treba da zaštite gornji deo tela (torzo) od dejstva uboda nožem i predmeta sa oštrim vrhom. Ovom projektu pristupili su UKPSDB (United Kingdom Police Scientific Development Branch) i USNIST
(United States National Institute of Standards and technology), što je rezultiralo standardom NIJ 0115.00, kao zajedničkom tehničkom dokumentu, koji preciznije definiše zahteve o obeležavanju, kriterijume za prijem i postupke merenja otiska u materijalu iza zaštitnog prsluka, odnoseći se u svojoj primeni isključivo na zaštitu od uboda nožem i predmeta sa oštrim vrhom. Zahvaljujući tome što u svojoj primeni standard NIJ 0115.00 isključuje sve druge vidove pretnji vezane za testiranje zaštitnih prsluka, poput balističkih (nastalih dejstvom vatrenog oružja), pretnji od povreda tupim ili energetskim $^{1}$ vrhom (slika 3 ), ovaj standard se smatra zasebnim u oblastima ispitivanja zaštitnih prsluka.

${ }^{1}$ U okviru NIJ standarda pod pojmom ,oružje sa energetskim vrhom" podrazumevaju se sva hladna oružja čiji vrh prenosi energiju napada na kontaktnu površinu u kontinuiranim talasima (vrhovi strela, kopalja i sl.). 


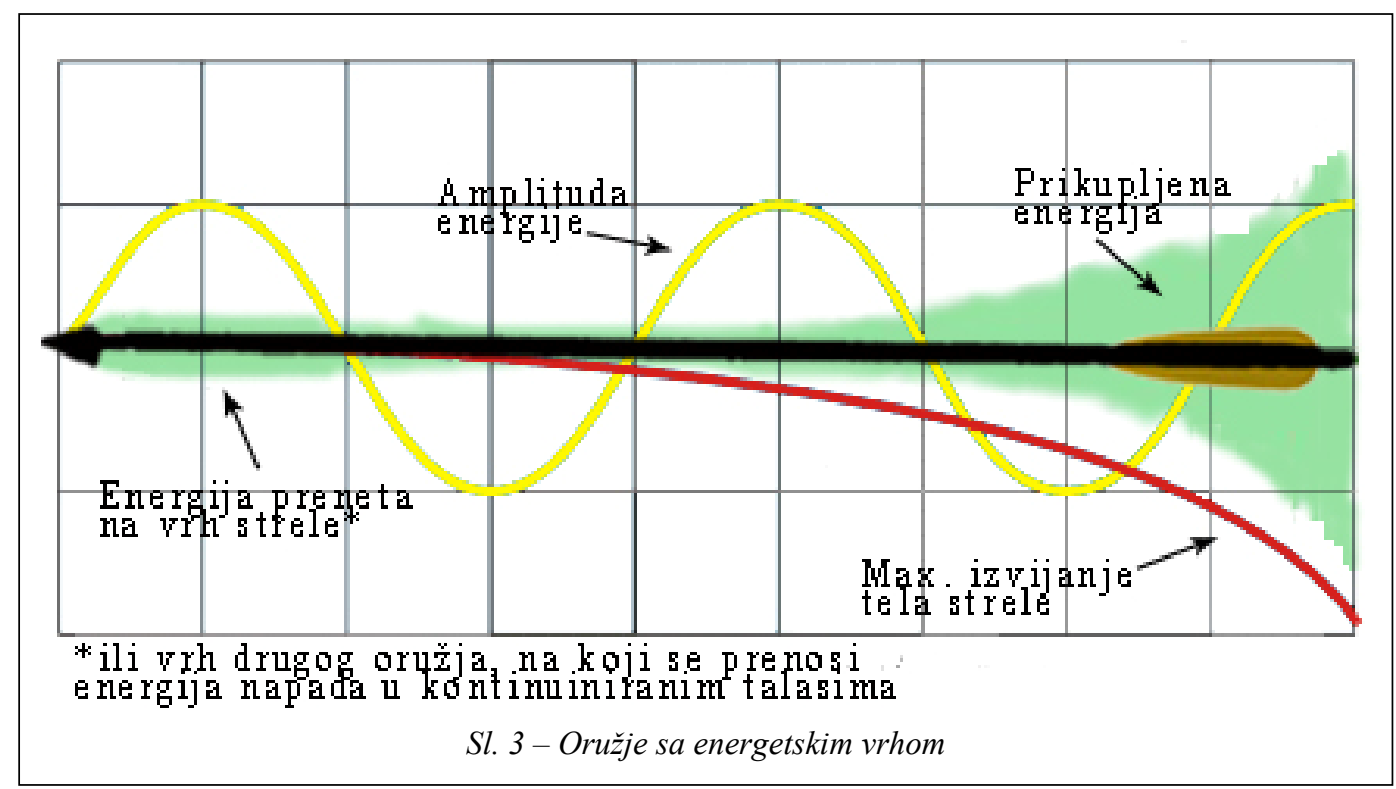

\section{Klasifikacija zaštitnih prsluka}

Svi zaštitni prsluci obuhvaćeni standardom NIJ 0115.00, u zavisnosti od vrste pretnji (nož ili šilo), klasifikuju se na dva tačno određena tipa zaštite:

- tip I, namenjen za zaštitu od uboda komercijalnih - mašinski izrađenih i naoštrenih sečiva - vrhova noža. Za ovaj tip zaštitnih prsluka koristi se komercijalna oznaka „EB“ (Edged Blade).

- tip II, namenjen za zaštitu od dejstva noža i predmeta sa oštrim vrhom, izrađenim od materijala lošijeg kvaliteta, improvizovane - ručne izrade i finiširanja (oštrenja). Ovaj tip zaštitnog prsluka nosi komercijalnu oznaku „S“ (Spike).

Pored samih tipova pretnji, prsluci namenjeni za zaštitu od uboda nožem i drugih predmeta sa oštrim vrhom klasifikuju se na tri različita nivoa zaštite, za čije određivanje se uzima nivo energije uboda $u$ trenutku udara u zaštitni prsluk. Energije uboda koje se koriste za određivanje nivoa zaštite, dobijene su testiranjem muškog dela populacije u periodu od 1997. do 1999. godine, koje je izvršila organizacija PSDB. Naime, uzimanjem aritmetičke sredine proizvedenih energija uboda, na osnovu tri najčešće tehnike uboda nožem ili predmetom sa oštrim vrhom (od gore, od dole, sa strane), došlo se do rezultata da: energiju najnižeg nivoa proizvodi $85 \%$ dela testirane populacije; energiju srednjeg nivoa - 90\% dela populacije, a energiju najvišeg nivoa - $96 \%$ dela testirane populacije.

Radi dobijanja što pouzdanijeg rezultata testiranja, bez obzira na to o kom nivou zaštite se radi, u standardu NIJ 0115.00 izričito se zahteva da svaki uzorak zaštitnog prsluka bude testiran sa dva različita nivoa energija uboda, uzimajući tako najnižu zadovoljenu vrednost energije uboda za određivanje nivoa zaštite prsluka (tabela 1). 
Tabela 1

NIJ 0115.00 - Nivoi zaštite u odnosu na energiju uboda nožem ili predmetom sa oštrim vrhom

\begin{tabular}{|c|c|c|c|c|c|}
\hline \multirow[t]{2}{*}{$\begin{array}{c}\text { Nivo } \\
\text { zaštite }\end{array}$} & \multicolumn{2}{|c|}{$\begin{array}{c}\text { „E1“ } \\
\text { osnovna energija } \\
\text { uboda }\end{array}$} & \multicolumn{2}{|c|}{ krajnja energija uboda } & \multirow[t]{2}{*}{$\begin{array}{l}\text { Način i } \\
\text { vreme } \\
\text { nošenja }\end{array}$} \\
\hline & $\mathrm{J}$ & $\mathrm{ft} \cdot \mathrm{lbf}$ & $\mathrm{J}$ & $\mathrm{ft} \cdot \mathrm{lbf}$ & \\
\hline 1 & $24 \pm 0,50$ & $17,7 \pm 0,36$ & $636 \pm 0,60$ & $26,6 \pm 0,44$ & $\underline{C}+\mathrm{ExW}$ \\
\hline 2 & $33 \pm 0,60$ & $24,3 \pm 0,44$ & $450 \pm 0,70$ & $36,9 \pm 0,51$ & $\underline{\mathrm{C} / \mathrm{O}+}$ \\
\hline 3 & $43 \pm 0,60$ & $31,7 \pm 0,44$ & $4 \quad 65 \pm 0,80$ & $47,9 \pm 0,59$ & $\underline{\mathrm{O}+\mathrm{SW}}$ \\
\hline \multicolumn{6}{|c|}{$\begin{array}{l}\text { Legenda: } \\
\underline{\underline{C}} \text { (Covert) - skriveni način nošenja zaštitnog prsluka - ispod } \\
\text { gornje odeće; } \underline{O} \text { (Overt) - otkriveni način nošenja zaštitnog } \\
\text { prsluka - iznad gornjeg ili kao gornji deo odeće, namenjeni } \\
\text { za nošenje u situacijama sa većim stepenom rizika; } \\
\underline{C / O} \text { (Covert/Overt) kombinacija nošenja u zavisnosti od } \\
\text { konkretne situacije i stepena rizika; ExW (Extended Wear)- } \\
\text { zaštitni prsluci namenjeni za neprekidno-produženo nošenje; } \\
\underline{S W} \text { (Short Wear) - zaštitni prsluci specijalne namene, koji se } \\
\text { upotrebljavaju u situacijama sa izuzetno visokim stepenom } \\
\text { rizika, velike težine i malog komfora pri nošenju. }\end{array}$} \\
\hline
\end{tabular}

Definisani nivo zaštite pruža mogućnost lakog određivanja načina i dužine nošenja zaštitnog prsluka. Tako se za određene tipove zaštite, $\mathrm{u}$ zavisnosti od proizvođača ili na zahtev krajnjeg korisnika, prsluci namenjeni za zaštitu od uboda nožem ili predmetima sa oštrim vrhom, izrađuju kao gotovi odevni predmeti: jakne, sakoi, kaputi ili prsluci sa zaštitnim umecima (panelima).

\section{Karakteristike zaštitnih prsluka}

Uzorkovanje zaštitnih prsluka obavlja se metodom slučajnog uzorka, tj. izdvajanjem najmanje tri kompletna $i$ ispravna prsluka, po mogućnosti što većih konfekcijskih veličina, radi povećanja verovatnoće da će se testiranje završiti na manjem broju kompleta prsluka. Najčešće se uzimaju uzorci prsluka koji odgovaraju za obime grudi od $117 \mathrm{~cm}(46,1$ in) do $122 \mathrm{~cm}(48,0 \mathrm{in})$, kada su u pitanju muškarci, ili od $107 \mathrm{~cm}(42,1$ in) do 112 cm (44,0 in), kada se radi o zaštitnim prslucima namenjenim ženama.

Potvrda (sertifikat) o ispravnosti predstavlja dokument u kojem proizvođač izjavljuje da proizvodna jedinica zaštitnog prsluka ispunjava ili premašuje sve zahteve ovog standarda za navedeni nivo zaštite.

Upadni ugao predstavlja ugao između linije udara noža ili predmeta sa oštrim vrhom i normale na tangentnu ravan do tačke udara (slika 4).

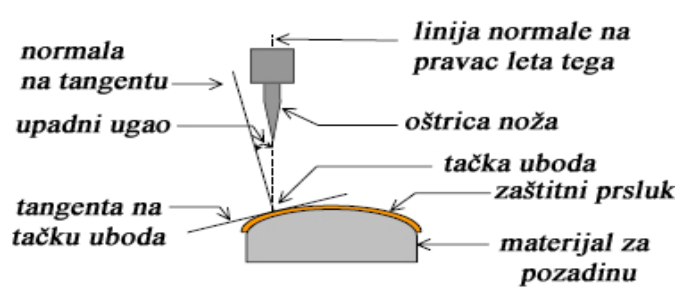

Sl. 4 - Upadni ugao

Materijal za pozadinu predstavlja izmodelirani blok, postavljen tako da bude u kontaktu sa zadnjom stranom ispitivanog uzorka prsluka za sve vreme ispitivanja. Minimalne dimenzije materijala za pozadinu treba da iznose $381 \mathrm{~mm}(15,0$ in) u dužinu i $305 \mathrm{~mm}$ (12,0 in) u širinu, koje se smatraju dovoljnim za kompletno naslanjanje ispitivanog dela prsluka.

Materijal za pozadinu sastavljen je od sledećih komponenti (slika 5):

- četiri spojena lista neoprenskog sunđera, ukupne debljine 5,8 mm (0,23 in);

- jedan list polietilenske pene, ukupne debljine $31 \mathrm{~mm}(0,23 \mathrm{in}) \mathrm{i}$ gustine od $33 \mathrm{~kg} / \mathrm{m}^{3}\left(2,06 \mathrm{lb} / \mathrm{ft}^{3}\right)$;

- dva lista prirodne gume, ukupne debljine $6,4 \mathrm{~mm}(0,25 \mathrm{in})$. 


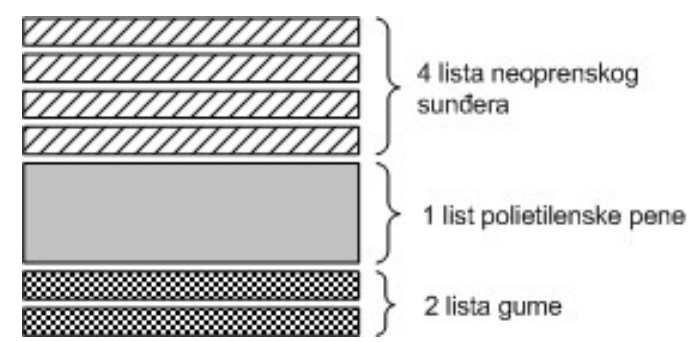

Sl. 5 - Materijal za pozadinu

Pre početka testiranja materijal za pozadinu treba da se kondicionira najmanje $12 \mathrm{~h}$, na temperaturi od $21^{\circ} \mathrm{C} \pm 6^{\circ} \mathrm{C}$ $\left(70^{\circ} \mathrm{F} \pm 10^{\circ} \mathrm{F}\right)$ i relativnoj vlažnosti od $50 \% \pm 20 \%$. Uslovi kondiciranja se mere pre i posle testa, kao i svaka $4 \mathrm{~h}$ za vreme trajanja testiranja, a njihove vrednosti se obavezno dokumentuju. Testiranje se obavlja tako što se čelična kugla, mase 1,042 $\mathrm{kg}(2,297 \mathrm{lb})$ i prečnika 45,5 $\pm 0,5 \mathrm{~mm}$ $(1,75 \pm 0,02$ in), pušta da slobodno pada sa visine od $1500 \mathrm{~mm} \pm 15 \mathrm{~mm}$ (59 in \pm 0,59 in) na udarnu stranu materijala za pozadinu, sa ciljem da se odbije na visinu od $450 \mathrm{~mm} \pm 102 \mathrm{~mm}(17,7 \mathrm{in} \pm 4,0 \mathrm{in})$.

Svako mesto udara mora se jasno obeležiti, tako da se pri narednom testu izbegne izlaganje iste površine materijala za pozadinu udaru čelične kugle, za čije se ispuštanje mogu koristiti cevi za navođenje ili slična sredstva, kako bi se osigurao potpun - ispravan kontakt udarnog kraja kugle sa udarnom površinom materijala za pozadinu.

Mokri diskovi prečnika $50 \mathrm{~mm} \pm 1$ $\mathrm{mm}(1,97$ in $\pm 0,04$ in) izrađuju se od iste vrste polietilenske pene korišćene u srednjem sloju materijala za pozadinu i postavljaju se radi popunjavanja dobijenih otisaka, nakon postizanja zadovoljavajućih rezultata testa materijala za pozadinu.

Ispravni pogoci ili ubodi zadovoljavaju sledeće uslove:

a) da se energija udara nalazi između vrednosti E1 i E2 (tabela 1); b) da se ubod ne nalazi bliže od 51 $\mathrm{mm}(2,0$ in) $\mathrm{u}$ odnosu na ivicu zaštitnog prsluka;

c) da se ubod ne nalazi bliže od 51 $\mathrm{mm}(2,0$ in) u odnosu na ivicu materijala za pozadinu;

d) da se ubod ne nalazi bliže od 51 $\mathrm{mm}(2,0$ in) u odnosu na prethodni ubod;

e) da odstupanje uboda u momentu pogađanja prsluka ne prelazi $\pm 5^{\circ}$ od planiranog upadnog ugla.

Označavanje mesta za ubod vrši se iscrtavanjem krugova pomoću šablona ili mernog uređaja, prema šemi prikazanoj na slici 6, u zavisnosti od vrste testa i uzorka. Sva označena mesta se ne moraju izložiti ubodu, već to zavisi od broja potrebnih pokušaja za dobijanje ispravnog pogotka.
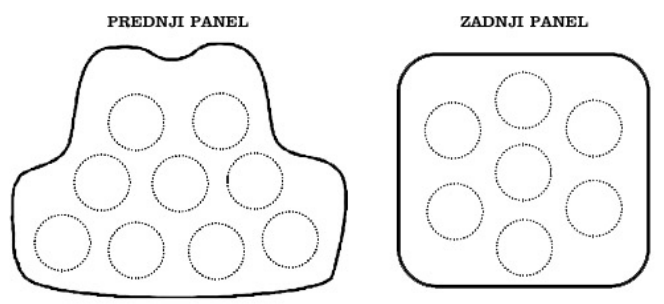

Sl. 6-Označavanje mesta za ubod

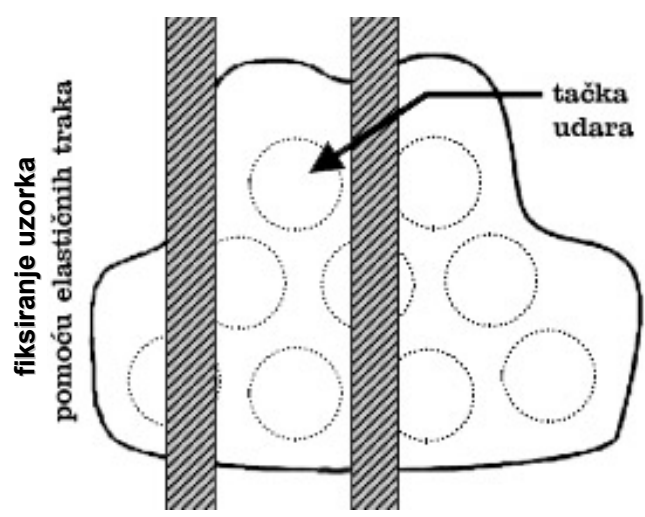

Sl. 7 - Učvršćivanje uzorka 


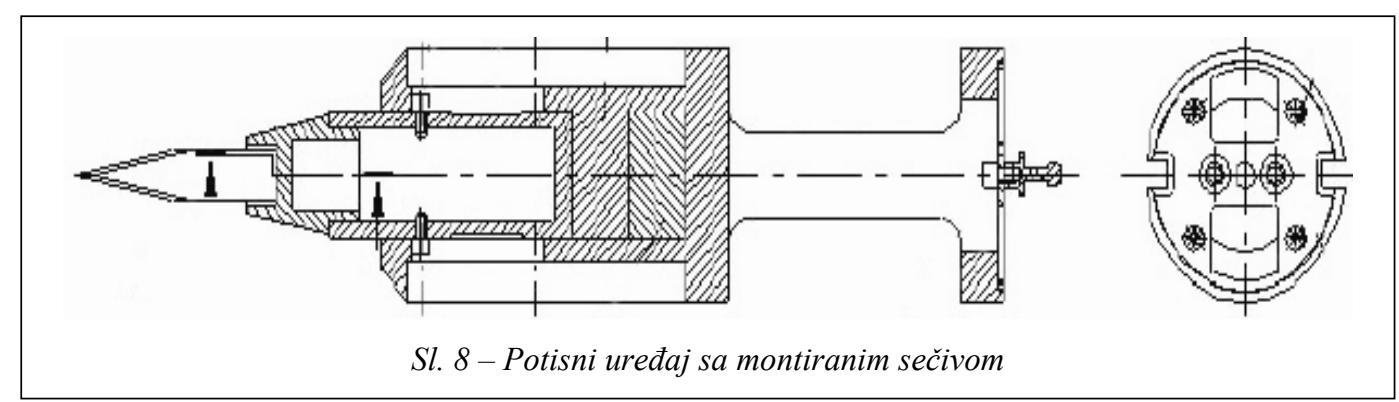

Učvršćivanje uzorka na materijalu za pozadinu obavlja se pomoću elastičnih traka širine $51 \mathrm{~mm}$ (2,0 in), kao što je prikazano na slici 7. Tako učvršćeni uzorak zaštitnog prsluka na materijalu za pozadinu nalazi se u horizontalnom položaju u odnosu na inženjerijski projektovani nož ili šilo, koji su pripremljeni za testiranje. Elastične trake treba da spreče sva eventualna pomeranja uzorka, koja mogu nastati u trenutku udara oružja, kao i da obezbede njegovo potpuno naleganje na materijalu za pozadinu. U slučaju da elastične trake na bilo koji način otežavaju ostvarivanje ispravnog pogotka, pomeraju se na drugo mesto, ali tako da se ne naruši naleganje uzorka na materijalu za pozadinu.

Potisni uređaj (slika 8) predstavlja čelični teg valjkastog oblika, koji na udarnoj strani ima konusni završetak sa aluminijumskom glavom u koji se postavlja inženjerski projektovan nož ili šilo (slika 9), čija izlazno-radna dužina iznosi $83 \mathrm{~mm} \pm 2 \mathrm{~mm}(3,27$ in $\pm 0,08$ in $)$.

Rastojanje konusne glave između donje - uže i gornje - šire tačke iznosi 30 $\mathrm{mm}(1,18$ in), radi nesmetanog testiranja panela zaštitnih prsluka pod uglom od $45^{\circ}$. Sa zadnje strane potisnog tega nalazi se najlonski konopac, koji obezbeđuje normalu pravca leta ovog uređaja. Tako- đe, sa zadnje strane potisnog tega montiraju se opruge, koje mogu uspešno da simuliraju pokrete ljudske ruke pri napadu i rasprostiranju energije uboda. Masa potisnog tega sa instaliranim oružjem iznosi $650 \mathrm{~g} \pm 7 \mathrm{~g}(1,43 \mathrm{lb} \pm 0,02 \mathrm{lb})$.

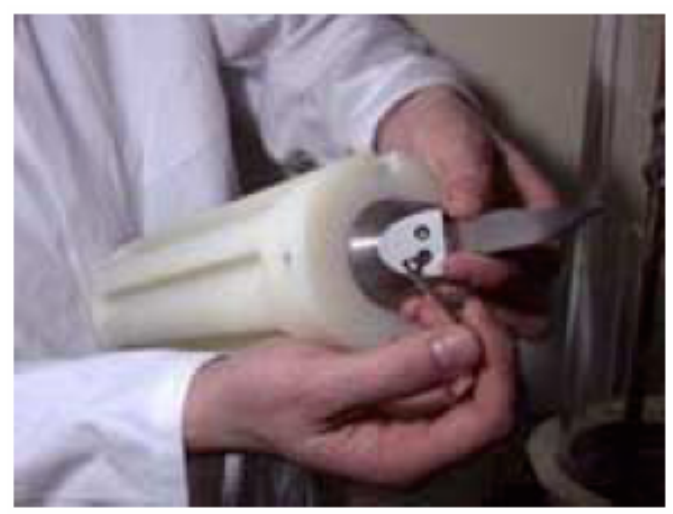

Sl. 9 - Montiranje sečiva u konusnu glavu potisnog uređaja

Inženjerski projektovani noževi predstavljaju dva posebno dizajnirana i izrađena tipa sečiva, koji se koriste u standardu NIJ 0115.00 za simulacije napada uboda nožem.

Prvo sečivo noža nosi oznaku „P1“ (slika 10) i služi za simulaciju napada od tipičnog malog noža, jednostrano naoštrenog i tankog tela, koji se može nositi u svakoj prilici, skriven u džepu ili za pojasom. 


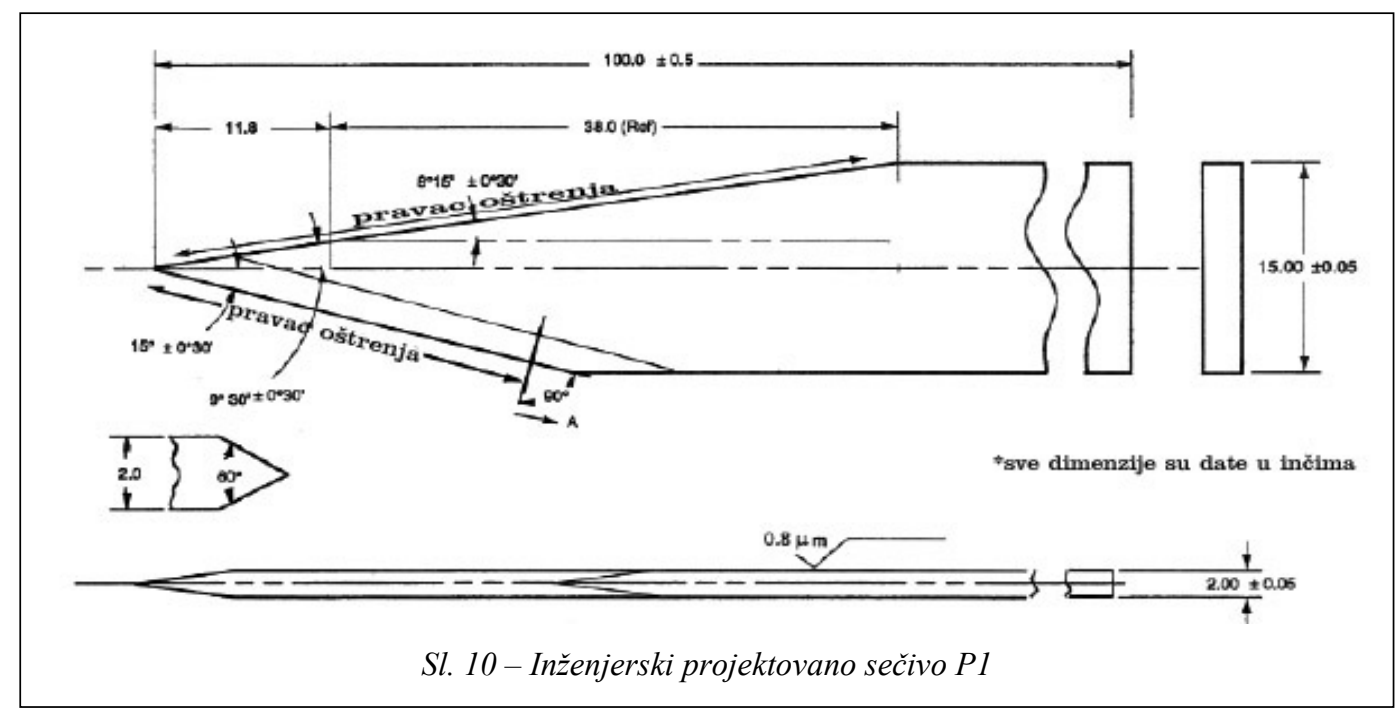

Drugo sečivo noža nosi oznaku „S1“" (slika 11) i služi za simulaciju napada sa većim sečivom, „commando“ oblika ili većeg kuhinjskog noža, koji ima obostrano naoštreno, debelo i robustno telo. Obe vrste inženjerski projektovanih sečiva imaju karakteristično izražen $i$ definisan vrh, koji je utemeljen u čvrstoj konstrukciji sečiva, tako da ne može doći do njegovog loma ili pucanja pri udaru od uzorka zaštitnog prsluka.
Inženjerski projektovano šilo predstavlja posebno dizajnirano i izrađeno oružje, koje po svojoj konstrukciji i izgledu podseća na šilo za led i u standardu NIJ 0115.00 koristi se za simulacije napada od oružja sa oštrim vrhom. Za potrebe testiranja u ovom segmentu standarda koristi se samo jedna vrsta šila, koje je izrađeno po uzoru na Kalifornijsko šilo za led „Californian Ice Pick“ (slika 12).

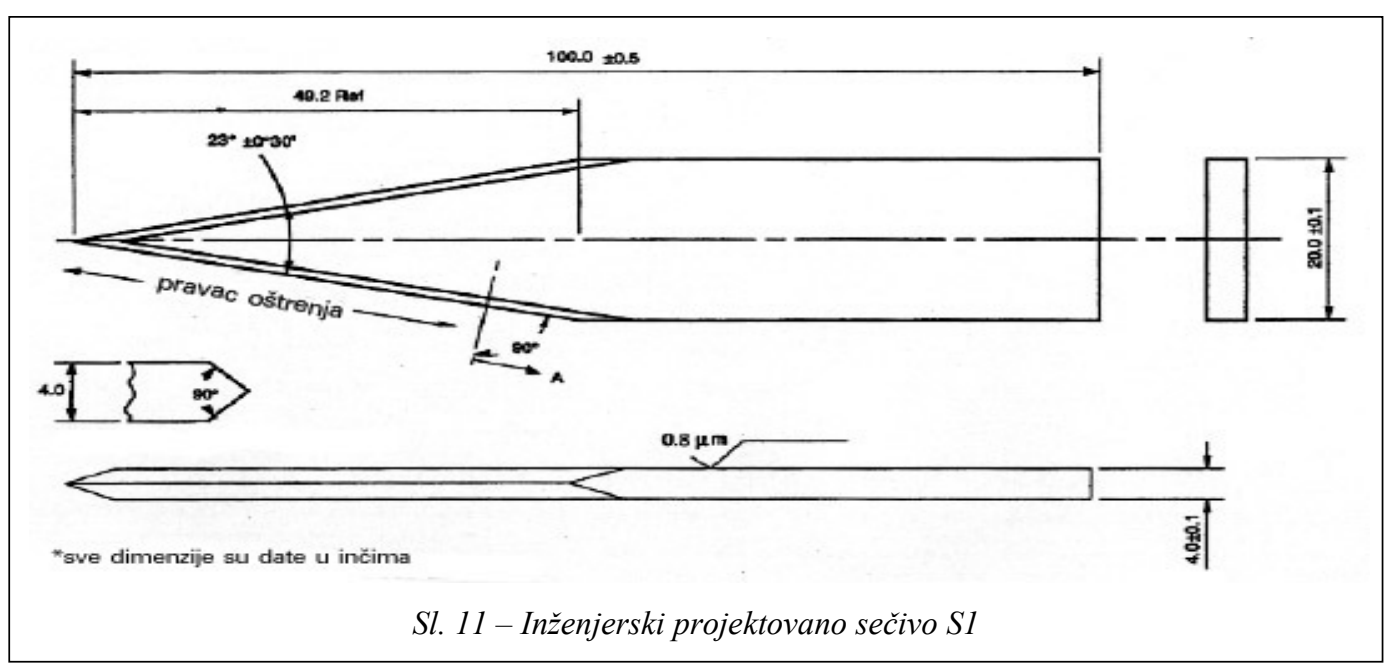




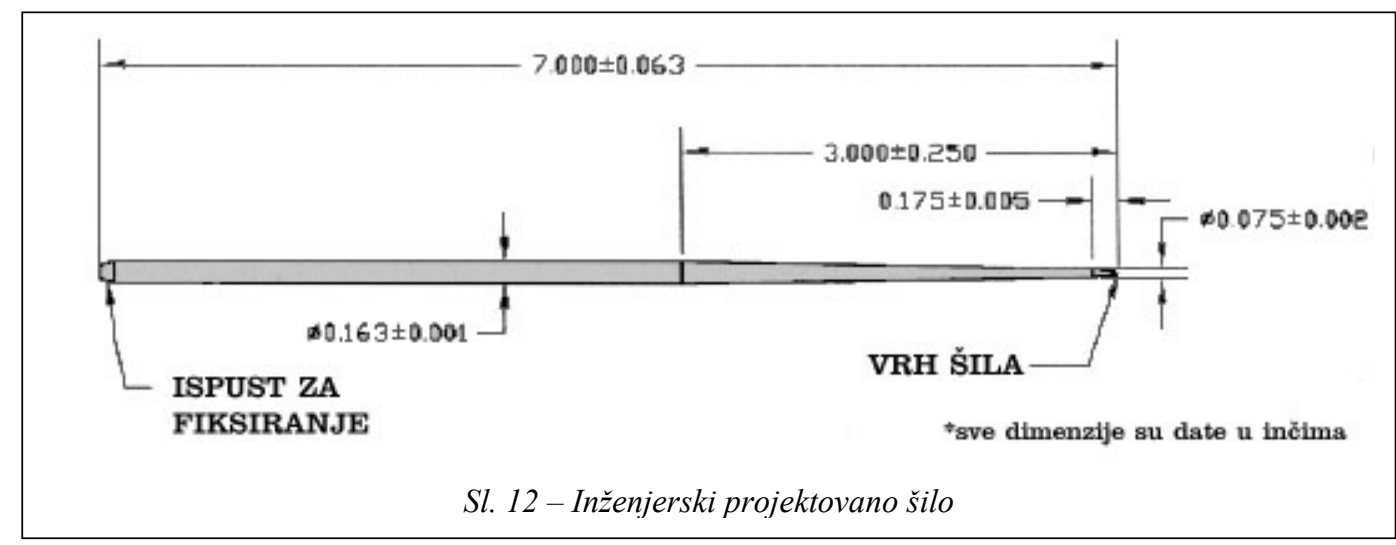

Stepen naoštrenosti utvrđuje se na mašini RHT (Rockwell Hardness Testing), vršeći pritisak inžinjerski projektovanim nožem ili šilom, u rasponu od 3 $\mathrm{kg}(6,61 \mathrm{lb})$ do $5 \mathrm{~kg}(11,0 \mathrm{lb})$, na aluminijumski blok čistoće od $99,997 \%$ i debljine od $5 \mathrm{~mm}$ (0,197 in), radi ostavljanja otisaka određene dubine, prema Rockwellovoj C skali (tabela 2).

Tabela 2

Određivanje stepena naoštrenosti inženjerski projektovanih sečiva prema Rockwellovoj C skali

\begin{tabular}{|c|c|c|c|c|c|c|c|c|c|}
\hline HRC & $\begin{array}{c}\text { Dubi- } \\
\text { na } \\
(\mathrm{mm})\end{array}$ & HRC & $\begin{array}{c}\text { Dubi- } \\
\text { na } \\
(\mathrm{mm})\end{array}$ & HRC & $\begin{array}{c}\text { Dubi- } \\
\text { na } \\
(\mathrm{mm})\end{array}$ & HRC & $\begin{array}{c}\text { Dubi- } \\
\text { na } \\
(\mathrm{mm})\end{array}$ & HRC & $\begin{array}{c}\text { Dubi- } \\
\text { na } \\
(\mathrm{mm})\end{array}$ \\
\hline-160 & 0,52 & -130 & 0,46 & -100 & 0,40 & -70 & 0,34 & -40 & 0,28 \\
\hline-150 & 0,50 & -120 & 0,44 & -90 & 0,38 & -60 & 0,32 & -30 & 0,26 \\
\hline-140 & 0,48 & -110 & 0,42 & -80 & 0,36 & -50 & 0,30 & -20 & 0,24 \\
\hline
\end{tabular}

Tačka udara predstavlja mesto na zaštitnom prsluku koje je predviđeno da bude izloženo udaru vrha noža ili šila.

Proboj (penetracija) iščitava se iza perforacija na uzorku zaštitnog prsluka, nastalih usled dejstva noža ili predmeta sa oštrim vrhom, te prisustvom oštećenja u vidu posekotina, rupa i sl.; u prvom sloju materijala za pozadinu ili rupama, zasekotinama, poderotinama i cepanjem papira Polyart $^{\mathrm{TM}}{ }^{2}$

${ }^{2}$ Papir za merenje otisaka u materijalu za pozadinu, čija osnovna masa iznosi $140 \mathrm{~g} / \mathrm{m}^{2}\left(0,46 \mathrm{oz} / \mathrm{ft}^{2}\right)$, a debljina 0,178 $\mathrm{mm}$ (7 mil).
Pod dubinom proboja podrazumeva se dužina vrha noža ili predmeta sa oštrim vrhom, koja izlazi iz zadnje strane prsluka (slika 13) .

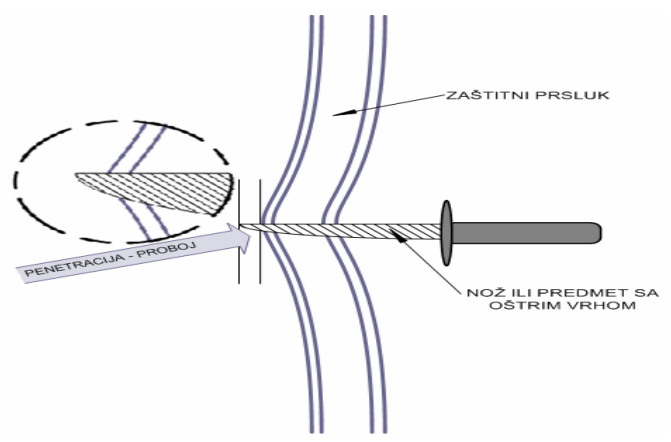

Sl. 13 - Penetracija zaštitnog prsluka

Polyart ${ }^{\mathrm{TM}}$ predstavlja vrstu papira koja se postavlja preko mokrih diskova i materijala za pozadinu, radi identifikacije (merenja) otisaka nastalih ubodom noža ili predmeta sa oštrim vrhom. Navedeni papir može se zameniti i nekom drugom vrstom papira, pod uslovom da pripada grupi sintetičkih papira izrađenih od polietilenskog filma visoke gustine, čija je osnovna odlika velika izdržljivost na cepanje.

Udarna (prednja) strana predstavlja površinu zaštitnog prsluka, koju je proizvođač zamislio kao površinu u koju treba da udari nož ili predmet sa oštrim vrhom i označava se natpisom. 
Zadnja strana je površina zaštitnog prsluka koja, po zamisli proizvođača, treba da se nosi prema telu korisnika.

Energija udara predstavlja proračunatu kinetičku energiju, koju poseduje vrh noža ili šila, u poziciji neposredno pre kontakta sa zaštitnim prslukom.

Zona za merenje brzine potisnog uređaja nalazi se iznad same tačke udara i njena dužina iznosi manje od $51 \mathrm{~mm}$ (2,0 in). U trenutku kada potisni teg dospe u najnižu tačku zone za merenje sopstvene brzine, vrh noža ili šila treba da se nalazi od $0 \mathrm{~mm}(0,0 \mathrm{in})$ do $25 \mathrm{~mm}(1,0$ in) iznad same tačke udara.

\section{Testiranje otpornosti zaštitnih prsluka na ubode nožem (,EB“' test)}

Celokupno „EB“ testiranje zaštitnih prsluka završava se nakon dobijanja 24 ispravna pogotka na dva kompletna prsluka (slika 14). Radi lakšeg praćenja redosleda sekvenci testiranja, prednji i zadnji paneli svakog zaštitnog prsluka označavaju se brojevima od 1 do 4 . U zavisnosti od ugla uboda, testiranje otpornosti zaštitnih prsluka na ubode nožem vrši se na načine prikazane u tabelama 3 i 4 .

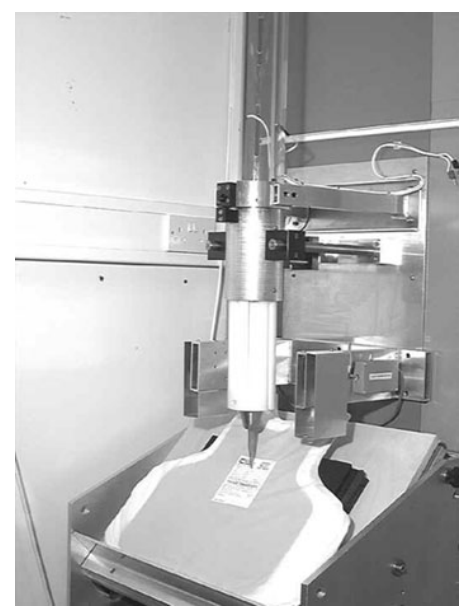

Sl. 14 - Testiranje zaštitnog prsluka
Tabela 3

Testiranje na ubode nožem pod uglom od $0^{\circ}$

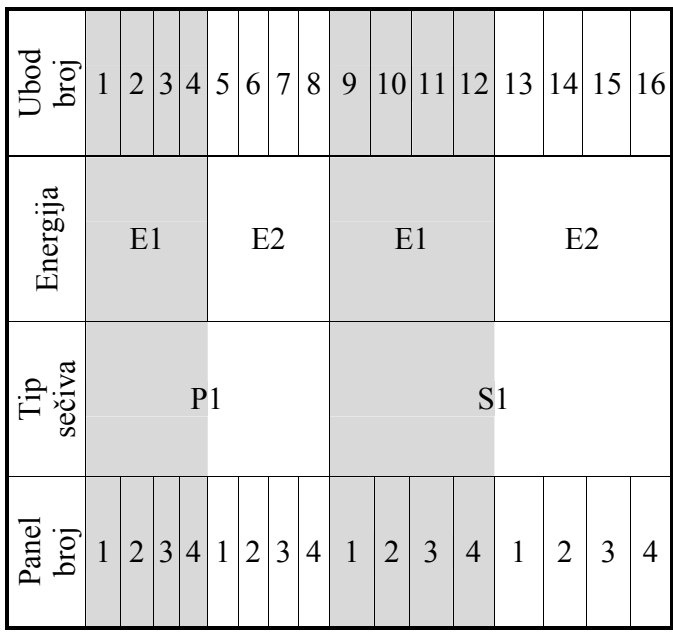

Celokupno „S“ testiranje zaštitnih prsluka završava se nakon dobijanja 12 ispravnih pogodaka na dva kompletna prsluka. Takođe, radi lakšeg praćenja redosleda sekvenci testiranja, kao i kod „EB“ testa, prednji i zadnji paneli svakog zaštitnog prsluka označavaju se brojevima od 1 do 4.

Tabela 4

Testiranje na ubode nožem pod uglom od $45^{\circ}$

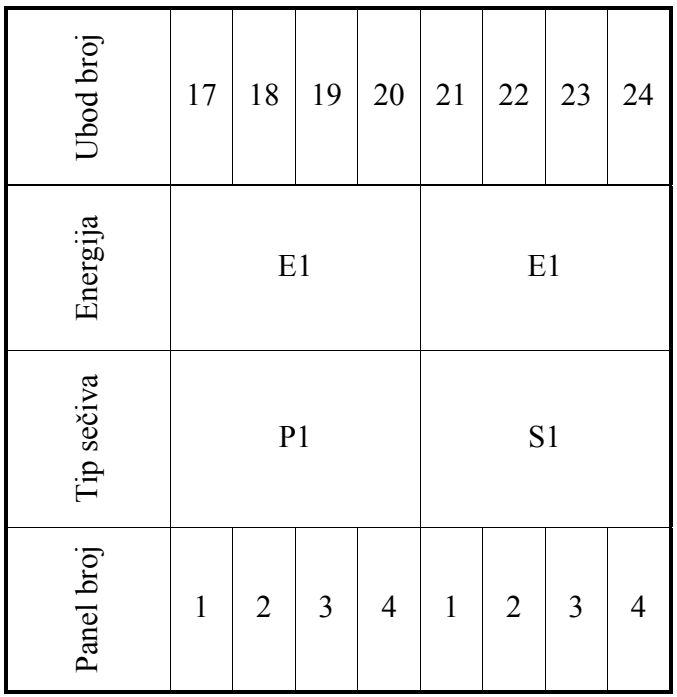


Testiranje otpornosti zaštitnih prsluka na ubode predmetima sa oštrim vrhom (,, S“ test)

U zavisnosti od ugla uboda, testiranje otpornosti zaštitnih prsluka na ubode oružjem sa oštrim vrhom obavlja se na način prikazan u tabeli 5 .

Tabela 5

Testiranje na ubode predmetima sa oštrim vrhom

\begin{tabular}{|c|c|c|c|c|c|c|c|c|c|c|c|c|}
\hline 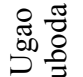 & \multicolumn{8}{|c|}{$0^{\circ}$} & \multicolumn{4}{|c|}{$45^{\circ}$} \\
\hline 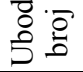 & 1 & 2 & 3 & 4 & 5 & 6 & 7 & 8 & 9 & 10 & 11 & 12 \\
\hline $\begin{array}{l}:=\frac{\pi}{20} \\
\frac{\overrightarrow{0}}{\vec{D}} \\
\text { 式 }\end{array}$ & \multicolumn{8}{|c|}{ E1 } & \multicolumn{4}{|c|}{ E1 } \\
\hline 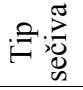 & \multicolumn{12}{|c|}{ S p i k e } \\
\hline 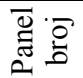 & 1 & 2 & 3 & 4 & 1 & 2 & 3 & 4 & 1 & 2 & 3 & 4 \\
\hline
\end{tabular}

\section{Tehnički zahtevi}

Kriterijumi za prijem ispunjeni su $\mathrm{u}$ slučajevima kada svi uzorkovani zaštitni prsluci zadovoljavaju zahteve u pogledu izrade, označavanja i kada svaki ispitani deo prsluka ispunjava zahteve u pogledu penetracije i deformacija definisanih standardom NIJ 0115.00.

Označavanje etiketom (etiketiranje) podrazumeva da se svaki set prsluka namenjenih za zaštitu od uboda nožem ili predmetima sa oštrim vrhom, jasno i trajno označi ,jednom“ etiketom sa jasno čitljivim slovima, u skladu sa nivoom zaštite i namenom zaštitnog prsluka.

U zavisnosti od toga da li se radi o označavanju zaštitnog panela, nosača paketa za neizmenljive panele ili spoljnim plaštovima sa izmenljivim panelima, na etiketama se nalaze različiti podaci:
Zaštitni panel treba da ima jednu etiketu, koja će se upotrebiti za označavanje spoljašnje površine panela, sa sledećim informacijama:

a) naziv, logotip ili druga oznaka za identifikaciju proizvođača, uključujući i njegovu adresu, telefon ili neki drugi način za kontakt;

b) oznaka za procenjeni nivo zaštite;

c) veličina (ako kupcu odgovara može da sadrži i ime pojedinca za koga je izrađen);

d) broj partije (lota);

e) datum proizvodnje;

f) datum isporuke;

g) model ili oblik koji jedinstveno identifikuje panel radi nabavke (paneli označeni da odgovaraju ženskom torzu treba da imaju posebno vidljiv natpis „ZA ŽENE“);

h) udarna strana ili zadnja strana površina panela, koja treba da bude izložena ili da se nosi uz telo mora da bude jasno obeležena („UDARNA STRANA“ ili „OVA STRANA IDE DO TELA“);

i) serijski broj;

j) uputstvo za održavanje balističkog materijala u skladu sa 16CFR $423^{* 3}$;

k) za zaštitne panele koji bi se, po proceni proizvođača, mogli izložiti dejstvu vatrenog oružja, (iako za to nisu namenjeni) štampa se upozorenje čija su slova najmanje dva puta veća od ostalih slova na etiketi (izuzev potrebnih informacija datih u tački ,a“), kojim se upozorava da prsluk nije namenjen za zaštitu od puščanih i pištoljskih zrna (promena boje slova je prihvatljiva, ali se ne može menjati njihov tip i veličina);

1) potvrda o saglasnosti sa standardom NIJ 0115.00.

CFR - Close Focus Research-Standard definiše posebne prateće parametre u oblastima istraživanja i testiranja u okviru Standarda malih oružja (Small Arms Standards). 
$\mathrm{Za}$ nosače paketa sa neizmenljivim zaštitnim panelima, pored etikete na zaštitnom panelu, treba da postoji etiketa na spoljnom ogrtaču, koja je u skladu sa zahtevima za zaštitne panele. U slučajevima kada je zaštitni prsluk konstruisan tako da etiketa na zaštitnom panelu nije pokrivena spoljnim ogrtačem, ona nije ni potrebna.

Spoljni ogrtač sa izmenljivim zaštitnim panelima treba da ima etiketu (e) na bilo kojoj spoljašnjoj strani. U slučajevima da je izrađen od jednog komada (npr. svi delovi su zajedno prošiveni u jednom komadu odeće) dovoljna je jedna etiketa, a ako se prednja i zadnja strana mogu razdvojiti, onda se etiketom označava i jedna i druga strana. Etiketa treba da sadrži sledeće informacije:

a) naziv, logotip ili drugu oznaku za identifikaciju proizvođača, uključujući adresu i telefon;

b) izjavu kojom se korisniku saopštava da pregleda zaštitne panele, kako bi se utvrdio nivo zaštite;

c) veličinu;

d) datum isporuke (ovu rubriku ispunjava kupac);

e) model ili oblik koji jedinstveno identifikuje panel radi nabavke (paneli označeni da odgovaraju ženskom torzu treba da imaju posebno vidljiv natpis ,za žene");

f) delovi i šavovi spoljnjeg ogrtača koji nisu ispunjeni zaštitnim panelima, treba da budu obeleženi natpisom „, ovom delu nema zaštite“, koji se prišiva sa obe strane;

g) uputstvo za održavanje ogrtača prsluka u skladu je sa propisom 16 CFR 423.

\section{Zaključak}

Očigledno je da rutinska upotreba odgovarajućeg zaštitnog prsluka znatno smanjuje verovatnoću fatalnog povređivanja, ali da je 100\%-tna zaštita u svim situacijama nemoguća. Izbor zaštitnog prsluka u izvesnom stepenu predstavlja kompromis između zaštite i komfora pri nošenju, odnosno masa i komfornost zaštitnog prsluka obrnuto su proporcionalni nivou zaštite koji se i obezbeđuje. Značajno je da onaj ko vrši nabavku zaštitnih prsluka, kao i svaki krajnji korisnik, treba da zna i razume zaštitu koju prsluk pruža, kao i sva njegova ograničenja.

Pre nabavke zaštitnog prsluka, namenjenog za zaštitu od uboda nožem ili predmetima sa oštrim vrhom, neophodno je proučiti Vodič NIJ 100-98 „Selection and Aplication Guide to Police Body Armor", koji detaljno opisuje problematiku izbora prsluka za ovakav specifičan vid pretnji. Standard NIJ 0115.00 predstavlja „otvoren“ dokument i podleže stalnim dopunama, radi pružanja što detaljnijih i pouzdanijih metoda testiranja, omogućujući krajnjim korisnicima koji imaju specijalne (više ili niže) zahteve u pogledu zaštite - mogućnost pouzdanog testiranja i drugačijih vidova pretnji u oblasti napada hladnim oružjem od opisanih u ovom standardu.

Literatura:

[1] National Institute of Justice. NIJ Standard-0101.04, Ballistic Resistance of Police Body Armor (2000).

[2] National Institute of Justice. NIJ Standard-0101.03, Ballistic Resistance of Police Body Armor (1987).

[3] American National Standards Institute. ,SAAMI Z299.31993: Voluntary Industry Standards for Pressure and Velocity of Center fire Pistol and Revolver Ammunition for the Use of Commercial Manufacturers", 1993.

[4] U. S. Army Test and Evaluation Command. TOP 2-2-710, Test Operations Procedure, Ballistic Tests of Armor Materials. (1999).

[5] Department of Defense. MIL-STD-662F, D o D Test Method Standard, V50 Ballistic Test for Armor. (1997 
